\title{
Corporate Social Responsibility and Customer Behavior: A Developing Country Perspective
}

\author{
Farida Saleem* and C. Gopinath**
}

\begin{abstract}
This study evaluates the determinants of customer behavior (brand loyalty and willingness to pay a price premium) within the framework of corporate social responsibility. We develop and test a model in the context of a developing country. The results reveal that customer CSR activities have an impact on customer behavior while environmental CSR activities have an insignificant impact. Trust appears to mediate the relationship between customer CSR and customer behavior, but remains insignificant in the relationship between environmental CSR and customer behavior.
\end{abstract}

Keywords: environmental CSR, customer CSR, brand loyalty, willingness to pay price premium.

JEL classification: G30, G38, G39.

\section{Introduction}

Corporate social responsibility (CSR) is not a new concept: the social role of business can be traced back centuries (Carroll, 1999; Smith, 2003). Bowen (1953) provided the first modern definition of CSR according to which businesses are not only responsible for their profit and loss statements, they are also responsible for the consequences of their actions in the wider sphere.

Increasingly, both shareholders and different stakeholders are demanding that firms take responsibility for the products they develop by following minimum standards of social and environmental responsibility (Fisher, Turner, \& Morling, 2009). Many consumer surveys claim that consumers' purchase decisions are influenced by a firm's CSR activities (Smith, 2003; Castaldo, Perrini, Misani, \& Tencati, 2009), although these surveys are not backed by empirical research on actual consumer behavior.

\footnotetext{
* Assistant Professor, Department of Business Administration, Fatima Jinnah Women University, Rawalpindi. Visiting Research Fellow Sawyer Business School, Suffolk University, Boston, USA.

** Associate Professor, Strategy and International Business Department, Sawyer Business School, Suffolk University, Boston, USA. Professor Jindal Business School Delhi, India.
} 
Some studies find a relationship between firm reputation and consumer intentions while others argue that the latter depends on many other factors (Bhattacharya \& Sen, 2004). Castaldo and Perrini (2004) observe that consumers are sometimes unable to consider or even fail to notice unacceptable social behavior on the part of a firm when making purchase decisions. Castaldo et al. (2009, p. 1) note: "If the impact of CSR reputation on consumers were universal and significant, we would see a clear impact on the bottom line of the firms with a strong social performance."

Firms' adoption of CSR practices varies across countries, depending on the social, political, and economic context (Chapple \& Moon, 2005; Kimber \& Lipton, 2005). Chapple and Moon (2005), Maignan and Ralston (2002), and Welford (2004, 2005) find there is a substantial country difference in CSR activities. Similarly, Ang (2000), Low (2004), Welford (2004), and Westwood and Posner (1997) point out that Asian firms lag far behind their Western counterparts in CSR practices. Recently, however, CSR activities have gained increased public attention in Asia (Baughn, Bodie, \& McIntosh, 2007; Ramasamy \& Ting, 2004).

This study focuses on Pakistani consumers' attitudes and buying behavior with respect to firms' CSR activities, where consumer trust is the mediator. Specifically, we test whether customer CSR and environmental CSR activities affect brand loyalty and willingness to pay premium prices.

\section{Literature Review}

The literature identifies two different approaches to CSR research (see Gray, Kouhy, \& Lavers, 1995). The first treats CSR as a supplement to economic activity and develops a link between CSR activities and the firm's financial performance; Gray, Owen, and Maunders (1988) and Mathews (1984) discuss its limitations in terms of scope and efficacy. The second approach to CSR places social and environmental reporting at the center of examination (Williamson, Lynch-Wood, \& Ramsay, 2006). However, more recent work points out the fit between the firm's core strategy and its CSR efforts (Bruch \& Walter, 2005; Porter \& Kramer, 2006). Sarkar (2008) also notes that business practices are now shifting from environmental management to environmental strategy.

CSR activities embrace a wide range of aspects, including programs and policies. Welford (2004, 2005), for instance, addresses 20 different aspects of CSR from commitment and local community protection to the development of a code of ethics and support for sustainable development. According to the model proposed by Carroll $(1979,1999)$, CSR can include 


\section{Perspective}

ethical, legal, economic, and philanthropic expectations from a firm, implying that it is not a uni-dimensional construct. The bulk of management science research focuses on environmental and ethical issues (see Lockett, Moon, \& Visser, 2006). Other studies, such as Maignan and Ferrell (2000), Maignan (2001), and Seifert, Morris, and Bartkus (2003), consider the multi-dimensionality of CSR. In some cases, however, only the social dimension is used to study this construct.

While CSR programs are usually directed toward a variety of stakeholder groups, this study specifically examines consumer groups. Within a consumer stakeholder group, CSR can help companies achieve better product evaluation (Brown \& Dacin, 1997), enhanced willingness to purchase, brand image (Fombrun, Gardberg, \& Barnett, 2000), and a positive attitude toward the company (Simon, 1995). Pirsch, Gupta, and Grau (2007) observe that certain CSR policies may not have a direct impact on consumers, who are likely to take a holistic view of these policies. They note that, "while a corporate environmental policy may only indirectly affect the consumer in the form of marginally cleaner air or water, its presence as a company policy would be perceived by consumers as a positive, enhancing their own view of the company's image" (p. 129).

To measure consumer perceptions of CSR, we use the model presented by Castaldo and Perrini (2004) and validated by Castaldo et al. (2009) in the context of fair-trade products. The model identifies three major dimensions of CSR: (i) environmental (firms' sensitivity toward environmental issues), (ii) consumer (focus on protecting consumers' rights and interests and on satisfying their needs), and (iii) employee (sensitivity toward issues such as equal economic treatment, health and safety practices). This study looks at the first two dimensions: environmental and consumer CSR.

\section{CSR and Brand Loyalty}

From the firm's point of view, customer loyalty refers to the benefit gained when a customer responds positively to a brand (Pirsch et al., 2007). Brand loyalty is associated with the economic benefits that accrue to a company when an increase in customer retention has a significant and positive impact on profits (Reichheld \& Sasser, 1990; Reichheld, 1996). It also helps generate competitive advantage (Pirsch et al., 2007), brand awareness, referrals, and a reluctance to defect (Duffy, 2003).

The relationship between brand loyalty and CSR has theoretical (Sen \& Bhattacharya, 2001) and empirical (de los Salmones, Crespo, \& del 
Bosque, 2005; Marin, Ruiz, \& Rubio, 2009; Perez-Batres, Doh, Miller, \& Pisani, 2012) support in the literature, but there is still only a limited body of knowledge on the alternative paths that link these two constructs (Martinez \& del Bosque, 2013). Loyal customers are a key strength for the firm, and socially responsive firms enjoy greater brand loyalty than those that do not consider CSR to be a core competency.

Ross, Stutts, and Patterson (1991) and Ross, Patterson, and Stutts (1992) show that consumers' willingness to buy products from a specific company is affected by the latter's involvement in social causes. Maignan, Ferrell, and Hult (1999) indicate that the importance customers ascribe to CSR activities can result in stronger loyalty to a firm. In this context, we put forward the following hypotheses:

- H1a: A firm's customer CSR activities have an impact on brand loyalty.

- H1b: A firm's environmental CSR activities have an impact on brand loyalty.

\section{CSR and Willingness to Pay Price Premium}

Aguilar and Vlosky (2007, p. 1100) define a price premium as "the amount of money an individual is willing to pay to secure a welfare improvement." Consumers tend to respond positively to products associated with a minimum level of social and environmental stewardship (Aguilar \& Vlosky, 2007), and they are often willing to pay a premium for these products (Loureiro \& Lotade, 2005; Govindasamy, DeCongelio, \& Bhuyan, 2006). On average, about 46 percent of consumers in Europe report a willingness to pay more for ethical products (MORI, 2000: cited in De Pelsmacker, Driesen, \& Rayp, 2006).

In a study by Hines and Ames (2000), 68 percent of consumers claimed that their purchase decision was influenced by the firm's responsible reputation. CRC-Consommation (1998: cited in De Pelsmacker et al., 2006) observes that French consumers were willing to pay 10-25 percent extra for apparel not made by child labor. Based on these findings, we propose the following hypotheses:

- H2a: A firm's customer CSR activities have an impact on the willingness to pay a price premium.

- H2b: A firm's environmental CSR activities have an impact on the willingness to pay a price premium 


\section{Perspective}

\section{CSR and Trust}

Trust is the belief that the product or service provider can be relied on to serve consumers' long-term interests (Crosby, Evans, \& Cowles, 1990). According to Pivato, Misani, and Tencati (2008, p. 6), trust is "an expectation that the trustee is willing to keep promises and to fulfill obligations." An immediate outcome of the company's social performance is the development of trust in its stakeholders (Pivato et al., 2008). Like any other stakeholder group, customers grade a company according to its behavior toward them. In understanding business relationships, trust plays a critical role, especially when the truster is in a high-risk position. This is a fundamental component of any business or nonbusiness relationship.

While studies have explored the influence of CSR on consumers in various ways (see Luo \& Bhattacharya, 2006), the focus on understanding the relationship between CSR and customer trust has shifted recently (Perrini, Castaldo, Misani, \& Tencati, 2010). Castaldo et al. (2009) finds that trust can have an impact on the success or failure of a socially responsible company in the marketplace. Similarly, Pivato et al. (2008) show that CSR activities help generate trust among consumers. For instance, customers associate greater satisfaction and trust with products that do not harm the environment (Balabanis, Phillips, \& Lyall, 1998). Based on these theoretical and empirical findings, we propose the following hypotheses:

- H3a: A firm's customer CSR activities have an impact on consumer trust.

- H3b: A firm's environmental CSR activities have an impact on consumer trust.

\section{Trust and Consumer Outcomes}

Given that mutual trust is vital for any successful social exchange, firms try to build trust with their stakeholders, including their customers. To enhance their self-esteem, customers try to identify with trustworthy organizations (Keh \& Xie, 2009). Their response toward a company is based on their perception of the identity of that company as trustworthy (Bhattacharya \& Sen, 2004).

Many studies (see, for example, Chaudhuri \& Holbrook, 2001; Sirdeshmukh, Singh, \& Sabol, 2002; Ball, Coelho, \& Machás, 2004) have identified the importance of trust in explaining brand loyalty. Reichheld and Schefter (2000, p. 107) note that, "to gain the loyalty of customers, you must first gain their trust." Empirical investigations of the marketing 
relationship theory also identify trust as an important mediator between corporate activities and brand loyalty (see Ball et al., 2004; Chaudhuri \& Holbrook, 2001). Trust is, therefore, an antecedent of brand loyalty (Singh \& Sirdeshmukh, 2000; Chaudhuri \& Holbrook, 2001).

Castaldo et al. (2009) study a sample of Italian consumers and show empirically that consumer trust translates into brand loyalty and willingness to pay a price premium. Based on these findings, we present the following hypotheses:

- H4a: Consumer trust has an impact on brand loyalty.

- H4b: Consumer trust has an impact on the willingness to pay a price premium.

Trust as a Mediator

The literature on service evaluation indicates that trust plays a mediating role in satisfaction and loyalty relationships (Sirdeshmukh et al., 2002). Our focus here is on linking CSR attributes with consumer outcomes through trust, where trust is based on "the expectation of ethically justifiable behavior" (Hosmer, 1995, p. 399). Given that CSR is about building moral capital (Godfrey, 2005), trust becomes a predictor of moral values (Vlachos, Tsamakos, Vrechopoulos, \& Avramidis, 2009) in the nexus between CSR and consumer outcomes (loyalty and willingness to pay a price premium). This yields the following hypotheses:

- H5a: Trust partially mediates the relationship between consumer CSR and consumer outcomes.

- H5b: Trust partially mediates the relationship between environmental CSR and consumer outcomes.

\section{Method}

We have used a structured questionnaire to collect the data for this study. Structural equation modeling (SEM) is generally recommended for large samples: for each observed variable, 20 observations are desirable with a minimum of 10 observations (Kline, 2011). We have 16 observed variables, which would require a minimum sample size of 160 to run SEM. A total of 500 questionnaires were distributed in two public sector universities in Rawalpindi and Islamabad; 307 completed questionnaires were returned, of which 297 were usable. The response rate was 59 percent. 


\section{Perspective}

Customer CSR and environmental CSR were measured using three items each adapted from Castaldo and Perrini (2004). ${ }^{1}$ Trust was measured using the four-item scale in Chaudhuri and Holbrook (2001), with items integrated from Wong and Sohal (2002) and Kennedy, Ferrell, and LeClair (2001). Brand loyalty was measured using a three-item scale from Castaldo et al. (2009), which also integrates the scales proposed by Yoo and Donthu (2001) and Kennedy et al. (2001). Finally, consumer willingness to pay a price premium was measured using a scale adapted from Chaudhuri and Holbrook (2001). Each observed variable in the model was measured on a Likert scale ranging from 1 ("strongly disagree") to 5 ("strongly agree"). Table 1 gives the variables, their items, and reliability measures (Cronbach's alpha).

Table 1: Latent and observed variables and Cronbach's alpha values

\begin{tabular}{lll}
\hline Variable & \multicolumn{1}{c}{ Observed variable } & Adapted from \\
\hline Customer CSR & CCSR1: X satisfies consumers' needs & Castaldo and \\
& CCSR2: X carefully checks origin of products & Perrini (2004) \\
& CCSR3: X protects consumers' rights & \\
Environmental & ECSR1: X cares for the natural environment & Castaldo and \\
CSR & ECSR2: X is attentive to recycling of materials & Perrini (2004) \\
& ECSR3: X is sensitive to ecological issues & \\
Trust & Trust1: You can count on X & Chaudhuri and \\
& Trust2: I trust X & Holbrook (2001) \\
& Trust3: Customers can always rely on X & \\
& Trust4: X keep their promises & Castaldo et al. \\
Brand loyalty & BL1: I will not buy other brands if X is available at & (2009) \\
& the store & \\
& BL2: I consider myself loyal to X & \\
BL3: $X$ is always my first choice & Chaudhuri and \\
pay price & WPPP1: Buying X seems smart to me even if they & Holbrook (2001) \\
premium & Cost more & \\
& WPPP2: I am ready to pay a higher price for X & \\
& WPPP3: I would still buy X if other brands & \\
& reduced their prices. &
\end{tabular}

The research instrument was developed in English, given that the respondents were university students able to respond easily. The survey form cites bottled water as the sample product - one that is easily available to students at universities and consumed regularly. Since environmental CSR is one of the constructs we use, the product packaging of the bottled water brand provides information on the firm's environmental initiatives.

\footnotetext{
${ }^{1}$ Perrini et al. (2010) measure these variables using the same items and validate them empirically.
} 
Given that self-reported data may be subject to the potential effect of common method variance (CMV) (see Podsakoff, MacKenzie, Lee, \& Podsakoff, 2003), we apply Harman's one-factor test prior to hypothesis testing. All the items are loaded within a principal component factor analysis (CFA) using verimax rotation; three factors with an Eigenvalue greater than 1 are formed and the first factor accounts for less than 50 percent of the variance. This result implies that the data is free of CMV.

The data is also tested to determine if it meets the basic SEM assumptions of normality, reliability, and validity. In this case, we look for univariate as well as multivariate normality. Univariate normality is tested for using skewness and kurtosis indices, which should lie between the absolute values of 3 and 10 (Kline, 2011). The skewness values for the study data lie between -1.366 and 0.430 , while the kurtosis values are between 1.357 and 1.990. This indicates the univariate normality of the dataset.

Multivariate normality is assessed using Mardia's coefficients of multivariate kurtosis (Gao, Mokhtarian, \& Johnston, 2008). A sample is considered to have a multivariate normal distribution at a 5 percent level of significance when the multivariate kurtosis value is less than 1.96 (Mardia, 1970). The critical ratio of Mardia's coefficient for the current dataset is 0.997 , indicating multivariate normality.

Cronbach's alpha values are used to check for internal consistency and reliability (calculated using SPSS 17). The alpha for the overall scale is 0.923, while those for each latent construct are between 0.897 and 0.933 . The composite reliability of the constructs is calculated using measurement model outputs. The composite reliability value is between 0.60 and 0.88 (Table 2).

Table 2: CFA of items present in model

\begin{tabular}{lcccc}
\hline Construct/variable & B & Alpha & CR & AVE \\
\hline Environmental CSR & & 0.897 & 0.60 & 0.31 \\
ECSR1 & 0.749 & & & \\
ECSR2 & 0.736 & & & \\
ECSR3 & 0.677 & & & \\
Customer CSR & & 0.933 & 0.78 & 0.54 \\
CCSR1 & 0.961 & & & \\
CCSR2 & 0.960 & & & \\
CCSR3 & 0.937 & & & \\
Trust & & 0.928 & 0.88 & 0.66 \\
\hline
\end{tabular}




\section{Perspective}

\begin{tabular}{lcccc}
\hline Construct/variable & B & Alpha & CR & AVE \\
\hline T1 & 0.902 & & & \\
T2 & 0.850 & & & \\
T3 & 0.939 & & & \\
T4 & 0.930 & & & \\
Brand loyalty & & 0.901 & 0.78 & 0.54 \\
BL1 & 0.943 & & & \\
BL2 & 0.940 & & & \\
BL3 & 0.961 & & & \\
Willingness to pay price premium & & 0.917 & 0.74 & 0.49 \\
WPPP1 & 0.827 & & & \\
WPPP2 & 0.941 & & & \\
WPPP3 & 0.941 & & & \\
\hline
\end{tabular}

Note: $\beta=$ standardized coefficient, alpha $=$ Cronbach's alpha, $C R=$ composite reliability, $\mathrm{AVE}=$ average variance extracted.

Source: Authors' calculations.

The data's convergent validity is evident from the significantly ( $p$ $<0.001$ ) loaded indicators for their respective constructs. The squared multiple correlation value of each observed variable is greater than 0.6 , indicating that each observed variable is successfully loaded on its respective latent construct (Table 3).

Table 3: Descriptive statistics, correlations, and shared variance

\begin{tabular}{|c|c|c|c|c|c|c|c|c|c|c|}
\hline & Variable & Item & Mean & SD & 1 & 2 & 3 & 4 & 5 & 6 \\
\hline 1 & ECSR & 3 & 2.72 & 1.02 & 0.69 & & & & & \\
\hline 2 & CCSR & 3 & 2.68 & 1.19 & $\begin{array}{l}0.75^{*} \\
(0.56)\end{array}$ & 0.78 & & & & \\
\hline 3 & Trust & 4 & 2.61 & 1.07 & $\begin{array}{c}0.75^{*} \\
(0.56)\end{array}$ & $\begin{array}{l}0.68^{*} \\
(0.46)\end{array}$ & 0.76 & & & \\
\hline 4 & BL & 3 & 2.71 & 1.09 & $\begin{array}{l}0.64^{*} \\
(0.41)\end{array}$ & $\begin{array}{l}0.70^{*} \\
(0.49)\end{array}$ & $\begin{array}{l}0.75^{*} \\
(0.56)\end{array}$ & 0.70 & & \\
\hline 5 & WPPP & 3 & 2.85 & 1.06 & $\begin{array}{l}0.78^{*} \\
(0.60)\end{array}$ & $\begin{array}{l}0.76^{*} \\
(0.58)\end{array}$ & $\begin{array}{l}0.63^{*} \\
(0.40)\end{array}$ & $\begin{array}{l}0.69^{*} \\
(0.48)\end{array}$ & 0.79 & \\
\hline
\end{tabular}

Note: Shared variance in parentheses, AVE in diagonal, ${ }^{*} \mathrm{p}<0.01$.

Source: Authors' calculations.

The model presented by Fornell and Larcker (1981) for assessing the discriminant validity of two or more factors suggests that the average variance extracted (AVE) of each construct should be compared with the shared variance between constructs. Discriminant validity exists when 
the AVE for a construct is greater than its shared variance with any other construct. After comparing these values, we conclude that there is no discriminant validity in any of the constructs.

\section{Results}

The first step of the incremental approach to SEM - fitting the CFA model - is carried out using the maximum likelihood estimation method. The results show that all the observed variables have a $t$-value greater than 2.50, their factor loadings are greater than 0.5 , and $\mathrm{R}^{2}$ is also greater than 0.5 . None of the observed variables are, therefore, removed from the model (see Jöreskog \& Sörbom, 1996). Similarly, there is no cross-loading of items and none of the items is removed on the basis of the model's modification indices. The results of the measurement model are given in Table 4.

Three models are compared to identify the best fit. The first contains three factors: the first factor includes the two dimensions of CSR, the second factor comprises trust, and the third factor includes all items under brand loyalty and willingness to pay a price premium. The second model contains four factors, with the items for customer and environmental CSR now loaded on separate factors. The third model (our hypothesized model) contains five factors - environmental CSR, customer CSR, trust, brand loyalty, and willingness to pay a price premium - all of which are loaded on separate factors. The fit statistics for each model and a comparison with the hypothesized model are reported in Table 4, which indicates that the hypothesized model is the best fitted model.

Table 4: Summary of CFA results

\begin{tabular}{lllcc}
\hline Model & $\chi^{2} \mathbf{( d f ) , ~ d f / \chi ^ { 2 }}$ & CFI & RMSEA & $\begin{array}{c}\text { Comparison with five- } \\
\text { factor model }\left(\Delta \chi^{2}, \mathbf{d f}\right)\end{array}$ \\
\hline Model 1 (3 factors) & 970, (101), 9.61 & 0.829 & 0.171 & $183,(3)$ \\
Model 2 (4 factors) & $787,(98), 8.02$ & 0.865 & 0.154 & $620,(4)$ \\
Model 3 (5 factors) & 167, (94), 1.77 & 0.986 & 0.051 & \\
\hline
\end{tabular}

Source: Authors' calculations.

The observed variables are loaded successfully on their respective constructs and fed into a structural model, the results of which are reported in Table 5. The standardized regression weights or beta weights given are used to assess the impact of the CSR dimensions on trust and the impact of trust on brand loyalty and willingness to pay a price premium. 


\section{Perspective}

Standardized regression weights greater than 0.5 are considered large and those between 0.5 and 0.1 are considered moderate (Kline, 2011). We find that customer CSR has a large impact on trust, with a standardized regression weight of 0.69 , while the effect of trust on brand loyalty and willingness to pay a price premium is moderate. The impact of environmental CSR is insignificant for all the proposed relationships.

Table 5: Structural model

\begin{tabular}{lcccc}
\hline Causal path & $\begin{array}{c}\text { Standardized } \\
\text { regression weights }\end{array}$ & $\begin{array}{c}\text { Un-standardized } \\
\text { coefficient }\end{array}$ & t-value & $\begin{array}{c}\text { Hypotheses } \\
\text { supported }\end{array}$ \\
\hline ECSR $=>$ Trust & 0.069 & 0.098 & 1.159 & No \\
ECSR $=>$ BL & 0.051 & 0.102 & 1.107 & No \\
ECSR $=>$ WPPP & 0.102 & 0.188 & 1.748 & No \\
CCSR $=>$ Trust & 0.690 & $0.607^{*}$ & 8.222 & Yes \\
CCSR $=>$ BL & 0.399 & $0.477^{*}$ & 7.031 & Yes \\
CCSR $=>$ WPPP & 0.401 & $0.439^{*}$ & 5.599 & Yes \\
Trust $=>$ BL & 0.465 & $0.607^{*}$ & 8.222 & Yes \\
Trust $=>$ WPPP & 0.279 & $0.334^{*}$ & 4.004 & Yes \\
\hline
\end{tabular}

Note: ${ }^{*}=$ significant at $0.01,{ }^{* *}=$ significant at 0.05 .

Source: Authors' calculations.

The full mediation framework presents acceptable, if poor, fit statistics $\left(\chi^{2}=258.6, \mathrm{df}=99, \chi^{2} / \mathrm{df}=2.612, \mathrm{RMSEA}=0.07, \mathrm{RMR}=0.127\right.$, $\mathrm{GFI}=0.90, \mathrm{AGFI}=0.86$, and $\mathrm{CFI}=0.96$ ), with a significant relationship between customer CSR and trust and between trust, customer loyalty, and willingness to pay a price premium. The partially mediated model fits the data well $\left(\chi^{2}=169.2, \mathrm{df}=95, \chi^{2} / \mathrm{df}=1.782, \mathrm{RMSEA}=0.05, \mathrm{RMR}=\right.$ 0.06 , GFI $=0.93$, AGFI $=0.91$, and CFI $=0.98$ ), identifying significant relationships between customer CSR and (i) trust, (ii) brand loyalty, and (iii) willingness to pay a price premium, as well as between trust and (i) brand loyalty and (ii) willingness to pay a price premium. However, the relationship with environmental CSR remains insignificant in both models. In addition, the chi-square difference test reveals that the partially mediated model is significantly better than the fully mediated model $\left(\chi^{2}\right.$ dif $=89.4, \mathrm{df}$ dif $\left.=4\right)$ (see Figures 1 and 2$)$.

Next, we apply the bootstrap method in AMOS to calculate the direct and indirect effects on brand loyalty and willingness to pay a price premium. The 2000 bootstrap re-samples with bias-corrected confidence intervals are calculated to measure the direct, indirect, and total effects as shown in Table 6. 


\section{Table 6: Mediation analysis}

2000 bootstrap re-sampling

\begin{tabular}{|c|c|c|c|c|c|c|c|c|c|c|c|c|}
\hline \multirow[b]{3}{*}{$\begin{array}{c}\text { CSR } \\
\text { dimension } \\
\end{array}$} & \multicolumn{3}{|c|}{$\begin{array}{l}\text { Direct effects on } \\
\text { WPPP }\end{array}$} & \multicolumn{3}{|c|}{$\begin{array}{l}\text { Indirect effects } \\
\text { through trust on } \\
\text { WPPP }\end{array}$} & \multicolumn{3}{|c|}{ Direct effects on BL } & \multicolumn{3}{|c|}{$\begin{array}{l}\text { Indirect effects } \\
\text { through trust on } B L\end{array}$} \\
\hline & \multicolumn{4}{|c|}{ BCCI } & \multicolumn{2}{|c|}{ BCCI } & \multicolumn{4}{|c|}{ BCCI } & \multicolumn{2}{|c|}{ BCCI } \\
\hline & Est. & $\mathbf{L}$ & $\mathbf{U}$ & Est. & $\mathbf{L}$ & $\mathbf{U}$ & Est. & $\mathbf{L}$ & $\mathrm{U}$ & Est. & $\mathbf{L}$ & $\mathbf{U}$ \\
\hline Customer & $0.439^{*}$ & 0.280 & 0.604 & $0.211^{*}$ & 0.100 & 0.337 & $0.477^{*}$ & 0.313 & 0.644 & $0.383^{*}$ & 0.269 & 0.515 \\
\hline Environmental & $0.188^{* *}$ & -0.014 & 0.368 & 0.033 & -0.017 & 0.099 & 0.102 & -0.068 & 0.312 & 0.060 & -0.035 & 0.162 \\
\hline
\end{tabular}

Note: $\mathrm{BCCI}=$ bias-corrected confidence interval, $\mathrm{L}=$ lower, $\mathrm{U}=$ upper, ${ }^{*}=$ significant at $0.01,{ }^{* *}=$ significant at 0.05 .

Source: Authors' calculations.

Figure 1: Fully mediated model

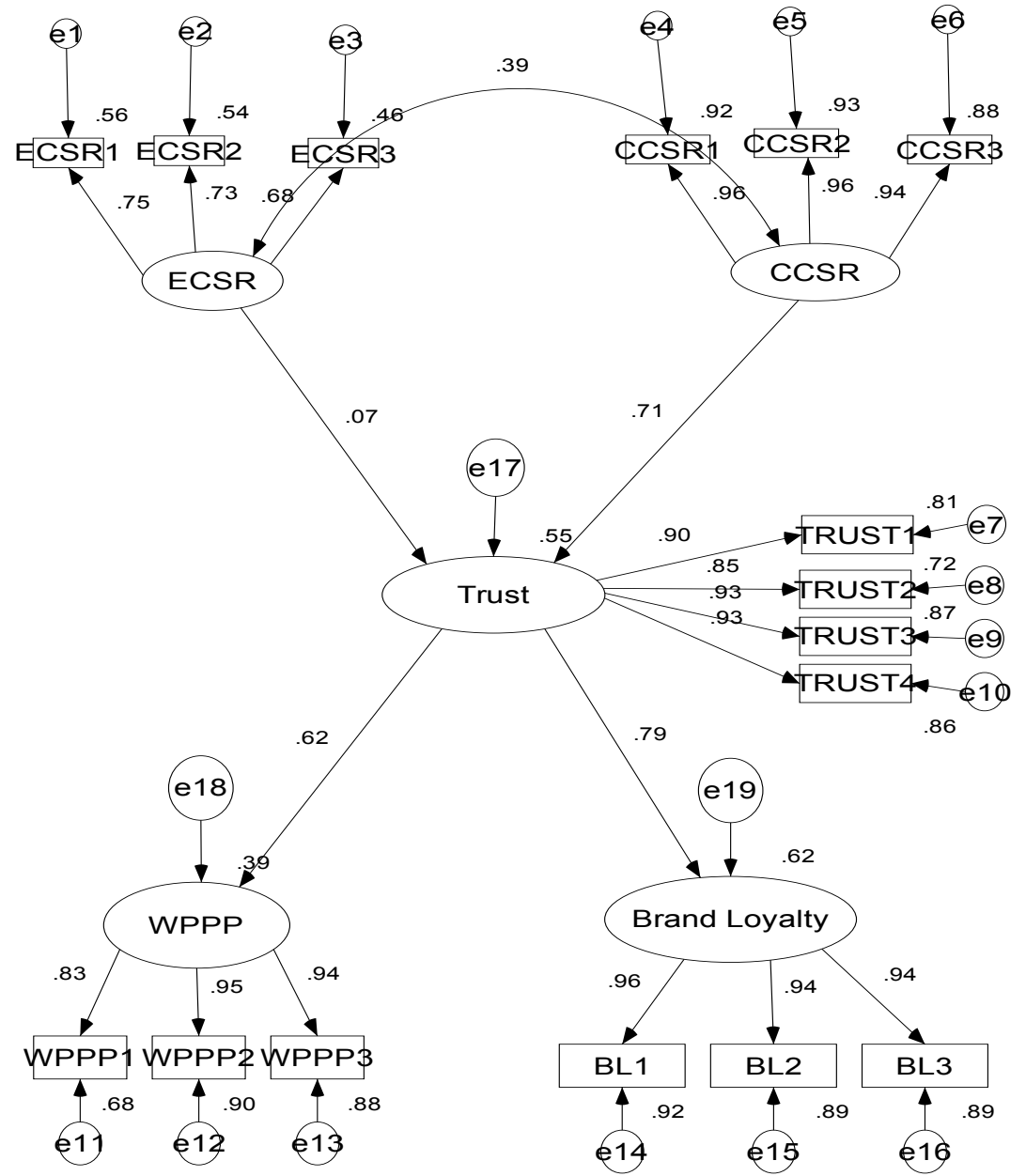

Source: Authors' calculations. 


\section{Perspective}

Figure 2: Partially mediated proposed model

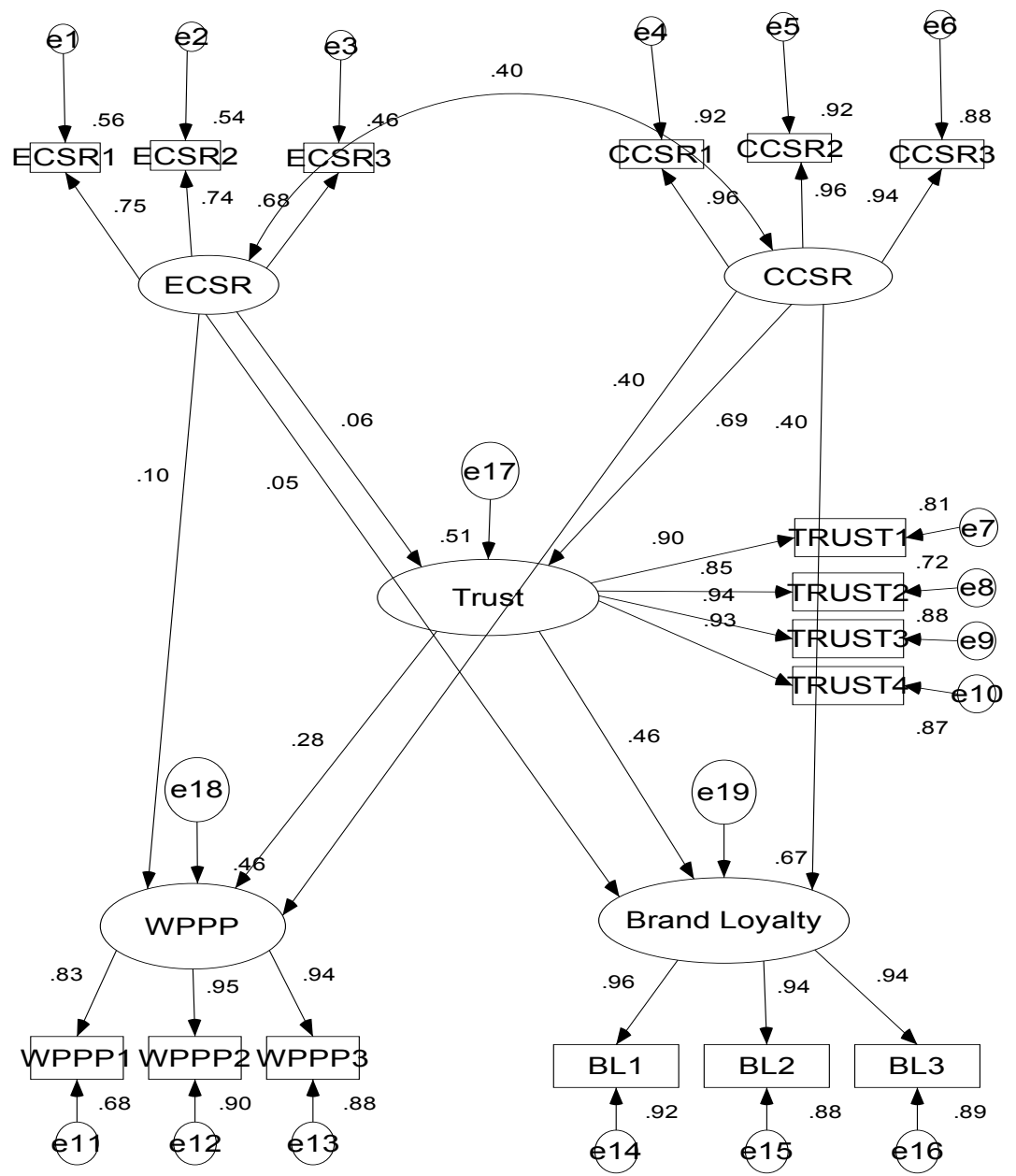

Source: Authors' calculations.

\section{Discussion}

The purpose of this study was to investigate the determinants of consumer behavior (brand loyalty and willingness to pay a price premium) in a developing country context. With consumer trust taken as the mediator, we look at CSR as one of the possible determinants of trust.

The study's most important finding is the insignificant relationship of environmental CSR with trust, brand loyalty, and willingness to pay a price premium. This result differs from previous findings (see Perrini et al., 2010), which, we suggest, can be explained by the differences in the two 
contexts. Developed economies enjoy high levels of literacy, political systems that encourage open debate, and greater social awareness important factors in building pressure against unacceptable environmental activities by firms. This pressure is applied through exit (changing suppliers) or voice (putting pressure on the supplier), both of which can be important triggers of change (Hirschman, 1970).

In developing countries, such awareness, if it exists at all, is only among a limited elite due to higher levels of illiteracy and lower exposure to global trends. Moreover, the need for low-priced products takes precedence over concerns about the environmental behavior of corporations. In a country such as Pakistan, where the official literacy rate is 57 percent, a combination of socioeconomic factors results in the public having a minimal interest in what organizations are doing to the natural environment in general. However, when such activities directly affect people's immediate environment, there is evidence that the community will push for firms to adopt pollution prevention technologies. LundThomsen (2004), who studies the pollution prevention programs of tanneries in Kasur, identifies the collective efforts of public welfare groups and local communities as major contributors to such programs.

One of the aims of CSR campaigns is to attract new customers and, as Etzion (2007) observes, when customers lack environmental awareness, "playing the green card" is not an effective strategy. The company used as a case study for data collection has also not used its environmental initiative as a marketing strategy. People in developing countries give more importance to the economic responsibilities of a firm compared to its noneconomic (including environmental) responsibilities (Farooq, Payaud, Merunka, \& Valette-Florence, 2014).

The absence of the importance of environmental CSR vis-à-vis the significant role of customer CSR is an apparent contradiction, but more recent literature (see Baughn et al., 2007; Ramasamy \& Ting, 2004) points out that CSR activities are gaining momentum in developing countries. This dimension of CSR is more prevalent in a developing country context where consumers are targeted directly by firms for CSR initiatives. Farooq et al. (2014) present similar results for Pakistan, although the study focuses on perceptions of CSR (of communities, customers, the environment, and employees) from an employee perspective and its impact on organizational trust. 
This study provides empirical support for trust as a mediating variable in the relationship between a firm and its customers. The results support Pivato et al. (2008), whose empirical findings identify trust as a key mediator in explaining the relationship between CSR policies and consumer behavior. Socially responsible companies have the capacity to use trust to gain competitive advantage. Our findings support the idea that customer CSR activities can generate trust among consumers and generate positive attitudes and behavior.

\section{Conclusion}

The data collected in this study should be interpreted carefully and in the economic and social context of Pakistan. It is not realistic to think about proactive consumerism in developing countries and one should be cautious about generalizing the situation in Pakistan as being true of all developing countries. Even within developing countries, different customer behavior is likely.

The significant impact of customer CSR and the insignificant impact of environmental CSR on trust, brand loyalty, and willingness to pay a price premium are important conclusions. This study, therefore, makes an important contribution to the literature by developing and testing a model that considers consumer and environmental CSR

activities to be drivers of positive customer behavior in a developing country context. 


\section{References}

Aguilar, F. X., \& Vlosky, R. P. (2007). Consumer willingness to pay price premiums for environmentally certified wood products in the US. Forest Policy and Economics, 9(8), 1100-1112.

Ang, S. H. (2000). The power of money: A cross-cultural analysis of business-related beliefs. Journal of World Business, 35(1), 43-60.

Balabanis, G., Phillips, H. C., \& Lyall, J. (1998). Corporate social responsibility and economic performance in the top British companies: Are they linked? European Business Review, 98(1), 25-44.

Ball, D., Coelho, P. S., \& Machás, A. (2004). The role of communication and trust in explaining customer loyalty: An extension to the ECSI model. European Journal of Marketing, 38(9/10), 1272-1293.

Baughn, C. C., Bodie, N. L., \& McIntosh, J. C. (2007). Corporate social and environmental responsibility in Asian countries and other geographical regions. Corporate Social Responsibility and Environmental Management, 14(4), 189-205.

Bhattacharya, C. B., \& Sen, S. (2004). Doing better at doing good. California Management Review, 47(1), 9-24.

Bowen, H. R. (1953). Social responsibilities of the businessman. New York, NY: Harper \& Row.

Brown, T. J., \& Dacin, P. A. (1997). The company and the product: Corporate associations and consumer product responses. Journal of Marketing, 61(1), 68-84.

Bruch, H., \& Walter, F. (2005). The keys to rethinking corporate philanthropy. MIT Sloan Management Review, 47(1), 49-55.

Carroll, A. B. (1979). A three-dimensional conceptual model of corporate performance. Academy of Management Review, 4(4), 497-505.

Carroll, A. B. (1999). Corporate social responsibility: Evolution of a definitional construct. Business and Society, 38(3), 268-295. 
Castaldo, S., \& Perrini, F. (2004, July). Corporate social responsibility, trust management and value creation. Paper presented at EGOS Colloquium on Trust in Hybrids, Ljubljana, Slovenia.

Castaldo, S., Perrini, F., Misani, N., \& Tencati, A. (2009). The missing link between corporate social responsibility and consumer trust: The case of fair trade products. Journal of Business Ethics, 84(1), 1-15.

Chapple, W., \& Moon, J. (2005). Corporate social responsibility (CSR) in Asia: A seven-country study of CSR website reporting. Business and Society, 44(4), 415-441.

Chaudhuri, A., \& Holbrook, M. B. (2001). The chain of effects from brand trust and brand affect to brand performance: The role of brand loyalty. Journal of Marketing, 65(2), 81-93.

Crosby, L. A., Evans, K. R., \& Cowles, D. (1990). Relationship quality in services selling: An interpersonal influence perspective. Journal of Marketing, 54(3), 68-81.

de los Salmones, M. M. G., Crespo, A. H., \& del Bosque, I. R. (2005). Influence of corporate social responsibility on loyalty and valuation of services. Journal of Business Ethics, 61(4), 369-385.

De Pelsmacker, P., Driesen, L., \& Rayp, G. (2006). Do consumers care about ethics? Willingness to pay for fair-trade coffee. Journal of Consumer Affairs, 39(2), 363-385.

Duffy, D. L. (2003). Internal and external factors which affect customer loyalty. Journal of Consumer Marketing, 20(5), 480-485.

Etzion, D. (2007). Research on organizations and the natural environment, 1992-present: A review. Journal of Management, 33(4), 637-664.

Farooq, O., Payaud, M., Merunka, D., \& Valette-Florence, P. (2014). The impact of corporate social responsibility on organizational commitment: Exploring multiple mediation mechanisms. Journal of Business Ethics, 125(4), 563-580.

Fisher, B., Turner, R. K., \& Morling, P. (2009). Defining and classifying ecosystem services for decision making. Ecological Economics, 68(3), 643-653. 
Fombrun, C. J., Gardberg, N. A., \& Barnett, M. L. (2000). Opportunity platforms and safety nets: Corporate citizenship and reputational risk. Business and Society Review, 105(1), 85-106.

Fornell, C., \& Larcker, D. F. (1981). Structural equation models with unobservable variables and measurement error: Algebra and statistics. Journal of Marketing Research, 18(3), 382-388.

Gao, S., Mokhtarian, P. L., \& Johnston, R. A. (2008). Nonnormality of data in structural equation models. Transportation Research Record: Journal of the Transportation Research Board, 2082, 116-124.

Godfrey, P. C. (2005). The relationship between corporate philanthropy and shareholder wealth: A risk management perspective. Academy of Management Review, 30(4), 777-798.

Govindasamy, R., DeCongelio, M., \& Bhuyan, S. (2006). An evaluation of consumer willingness to pay for organic produce in the northeastern US. Journal of Food Products Marketing, 11(4), 3-20.

Gray, R., Kouhy, R., \& Lavers, S. (1995). Corporate social and environmental reporting: A review of the literature and a longitudinal study of UK disclosure. Accounting, Auditing and Accountability Journal, 8(2), 47-77.

Gray, R., Owen, D., \& Maunders, K. (1988). Corporate social reporting: Emerging trends in accountability and the social contract. Accounting, Auditing and Accountability Journal, 1(1), 6-20.

Hines, C., \& Ames, A. (2000). Ethical consumerism: A research study conducted for The Co-Operative Bank. London: MORI.

Hirschman, A. O. (1970). Exit, voice, and loyalty: Responses to decline in firms, organizations, and states. Cambridge, MA: Harvard University Press.

Hosmer, L. T. (1995). Trust: The connecting link between organizational theory and philosophical ethics. Academy of Management Review, 20(2), 379-403.

Jöreskog, K. G., \& Sörbom, D. (1996). LISREL 8: User's reference guide. Skokie, IL: Scientific Software International. 
Keh, H. T., \& Xie, Y. (2009). Corporate reputation and customer behavioral intentions: The roles of trust, identification and commitment. Industrial Marketing Management, 38(7), 732-742.

Kennedy, M. S., Ferrell, L. K., \& LeClair, D. T. (2001). Consumers' trust of salesperson and manufacturer: An empirical study. Journal of Business Research, 51(1), 73-86.

Kimber, D., \& Lipton, P. (2005). Corporate governance and business ethics in the Asia-Pacific region. Business and Society, 44(2), 178-210.

Kline, R. B. (2011). Principles and practice of structural equation modeling. New York, NY: Guilford Press.

Lockett, A., Moon, J., \& Visser, W. (2006). Corporate social responsibility in management research: Focus, nature, salience and sources of influence. Journal of Management Studies, 43(1), 115-136.

Loureiro, M. L., \& Lotade, J. (2005). Do fair trade and eco-labels in coffee wake up the consumer conscience? Ecological Economics, 53(1), 129-138.

Low, C. K. (2004). A road map for corporate governance in East Asia. Northwestern Journal of International Law and Business, 25, 165-203.

Lund-Thomsen, P. (2004). Towards a critical framework on corporate social and environmental responsibility in the South: The case of Pakistan. Development, 47(3), 106-113.

Luo, X., \& Bhattacharya, C. B. (2006). Corporate social responsibility, customer satisfaction, and market value. Journal of Marketing, 70(4), 1-18.

Maignan, I. (2001). Consumers' perceptions of corporate social responsibilities: A cross-cultural comparison. Journal of Business Ethics, 30(1), 57-72.

Maignan, I., \& Ferrell, O. C. (2000). Measuring corporate citizenship in two countries: The case of the United States and France. Journal of Business Ethics, 23(3), 283-297. 
Maignan, I., Ferrell, O. C., \& Hult, G. T. M. (1999). Corporate citizenship: Cultural antecedents and business benefits. Journal of the Academy of Marketing Science, 27(4), 455-469.

Maignan, I., \& Ralston, D. A. (2002). Corporate social responsibility in Europe and the US: Insights from businesses' self-presentations. Journal of International Business Studies, 33(3), 497-514.

Mardia, K. V. (1970). Measures of multivariate skewness and kurtosis with applications. Biometrika, 57(3), 519-530.

Marin, L., Ruiz, S., \& Rubio, A. (2009). The role of identity salience in the effects of corporate social responsibility on consumer behavior. Journal of Business Ethics, 84(1), 65-78.

Martínez, P., \& del Bosque, I. R. (2013). CSR and customer loyalty: The roles of trust, customer identification with the company and satisfaction. International Journal of Hospitality Management, 35, 89-99.

Mathews, M. R. (1984). A suggested classification for social accounting research. Journal of Accounting and Public Policy, 3(3), 199-221.

Perez-Batres, L. A., Doh, J. P., Miller, V. V., \& Pisani, M. J. (2012). Stakeholder pressures as determinants of CSR strategic choice: Why do firms choose symbolic versus substantive self-regulatory codes of conduct? Journal of Business Ethics, 110(2), 157-172.

Perrini, F., Castaldo, S., Misani, N., \& Tencati, A. (2010). The impact of corporate social responsibility associations on trust in organic products marketed by mainstream retailers: A study of Italian consumers. Business Strategy and the Environment, 19(8), 512-526.

Pirsch, J., Gupta, S., \& Grau, S. L. (2007). A framework for understanding corporate social responsibility programs as a continuum: An exploratory study. Journal of Business Ethics, 70(2), 125-140.

Pivato, S., Misani, N., \& Tencati, A. (2008). The impact of corporate social responsibility on consumer trust: The case of organic food. Business Ethics: A European Review, 17(1), 3-12.

Podsakoff, P. M., MacKenzie, S. B., Lee, J. Y., \& Podsakoff, N. P. (2003). Common method biases in behavioral research: A critical review 
of the literature and recommended remedies. Journal of Applied Psychology, 88(5), 879-903.

Porter, M. E., \& Kramer, M. R. (2006). Strategy and society: The link between competitive advantage and corporate social responsibility. Harvard Business Review, 84(12), 78-92.

Ramasamy, B., \& Ting, H. W. (2004). A comparative analysis of corporate social responsibility awareness: Malaysian and Singaporean firms. Journal of Corporate Citizenship, 13, 109-123.

Reichheld, F. F. (1996). The loyalty effect: The hidden force behind growth, profits, and lasting value. Cambridge, MA: Harvard Business School Press.

Reichheld, F. F., \& Sasser, W. E. (1990). Zero defections: Quality comes to services. Harvard Business Review, 68(5), 105-111.

Reichheld, F. F., \& Schefter, P. (2000). E-loyalty: Your secret weapon on the web. Harvard Business Review, 78(4), 105-113.

Ross, J. K., Patterson, L., \& Stutts, M. A. (1992). Consumer perceptions of organizations that use cause-related marketing. Journal of the Academy of Marketing Science, 20(1), 93-97.

Ross, J. K., Stutts, M. A., \& Patterson, L. (1991). Tactical considerations for the effective use of cause-related marketing. Journal of Applied Business Research, 7(2), 58-65.

Sarkar, R. (2008). Public policy and corporate environmental behavior: A broader view. Corporate Social Responsibility and Environmental Management, 15(5), 281-297.

Seifert, B., Morris, S. A., \& Bartkus, B. R. (2003). Comparing big givers and small givers: Financial correlates of corporate philanthropy. Journal of Business Ethics, 45(3), 195-211.

Sen, S., Bhattacharya, C. B., \& Korschun, D. (2006). The role of corporate social responsibility in strengthening multiple stakeholder relationships: A field experiment. Journal of the Academy of Marketing Science, 34(2), 158-166.

Simon, F. L. (1995). Global corporate philanthropy: A strategic framework. International Marketing Review, 12(4), 20-37. 
Singh, J., \& Sirdeshmukh, D. (2000). Agency and trust mechanisms in consumer satisfaction and loyalty judgments. Journal of the Academy of Marketing Science, 28(1), 150-167.

Sirdeshmukh, D., Singh, J., \& Sabol, B. (2002). Consumer trust, value, and loyalty in relational exchanges. Journal of Marketing, 66(1), 15-37.

Smith, N. C. (2003). Corporate social responsibility: Not whether, but how (Working Paper No. 03-701). London: London Business School, Center for Marketing.

Vlachos, P. A., Tsamakos, A., Vrechopoulos, A. P., \& Avramidis, P. K. (2009). Corporate social responsibility: Attributions, loyalty, and the mediating role of trust. Journal of the Academy of Marketing Science, 37(2), 170-180.

Welford, R. J. (2004). Corporate social responsibility in Europe and Asia: Critical elements and best practice. Journal of Corporate Citizenship, $13,31-47$.

Welford, R. J. (2005). Corporate social responsibility in Europe, North America and Asia: 2004 survey results. Journal of Corporate Citizenship, 17, 33-52

Westwood, R. I., \& Posner, B. Z. (1997). Managerial values across cultures: Australia, Hong Kong and the United States. Asia Pacific Journal of Management, 14(1), 31-66.

Williamson, D., Lynch-Wood, G., \& Ramsay, J. (2006). Drivers of environmental behavior in manufacturing SMEs and the implications for CSR. Journal of Business Ethics, 67(3), 317-330.

Wong, A., \& Sohal, A. (2002). An examination of the relationship between trust, commitment and relationship quality. International Journal of Retail and Distribution Management, 30(1), 34-50.

Yoo, B., \& Donthu, N. (2001). Developing and validating a multidimensional consumer-based brand equity scale. Journal of Business Research, 52(1), 1-14. 